\title{
Grapsid crabs mediate link between mangrove litter production and estuarine planktonic food chains
}

\author{
J. Werry, S. Y. Lee* \\ Centre for Aquatic Processes and Pollution (CAPP), and School of Environmental and Applied Sciences, Griffith University \\ Gold Coast, PMB 50, Gold Coast MC, Queensland 9726, Australia
}

\begin{abstract}
The fate of crab-processed mangrove Avicennia marina leaf litter was compared with decomposition of whole leaf litter of A. marina and Rhizophora stylosa. Shredding by the grapsid crab Parasesarma erythodactyla resulted in reduction of mangrove leaf litter to fragments $\sim 200 \mu \mathrm{m}$ in the faecal material. The $\mathrm{C} / \mathrm{N}$ ratio decreased linearly with time, attaining $\sim 20$ after $28 \mathrm{~d}$. While the $\delta^{13} \mathrm{C}$ signature remained constant, the $\delta^{15} \mathrm{~N}$ value steadily changed from $\sim 4 \%$ o to $1.8 \%$ over $4 \mathrm{wk}$. Decomposing whole leaf litter, however, showed only modest increases in $\% \mathrm{~N}$ content with time, attaining a C/N ratio of $\sim 20$ only after $24 \mathrm{wk}$, with no significant temporal trend in either $\delta^{13} \mathrm{C}$ or $\delta^{15} \mathrm{~N}$. $\delta^{15} \mathrm{~N}$ of decomposing crab faecal material was significantly negatively correlated with surface bacteria density. Demonstrating a sigmoid pattern of increase, surface bacteria density on crab-processed leaf fragments was $\sim 70$ times higher than that on whole leaf litter after $28 \mathrm{~d}$ of decomposition. Analysis of the $\mathrm{C} / \mathrm{N}$ ratio, $\delta^{13} \mathrm{C}$ and $\delta^{15} \mathrm{~N}$ signatures of micro-POM collected from 5 mangrove waterways in southern Moreton Bay, Australia, failed to detect significant differences in these parameters at 3 distances from mangrove forests, but location of the waterways had a strong effect. In laboratory feeding experiments involving the copepods Temora turbinata and Oithona rigidis, a diet of faecal material from crabs significantly improved copepod survivorship compared with a diet of the alga Nannochloropsis sp. or the no-food treatment for both copepods. Stable isotope analysis of the copepods suggest that the animals were able to utilise both crab faecal material and algal carbon, with greater assimilation of the former food source, in the mixed diet (Nannochloropsis + crab faeces) treatment. By acting as shredders, grapsid crabs process large quantities and effect rapid enrichment of mangrove organic production, potentially benefiting both benthic and pelagic estuarine consumers.
\end{abstract}

KEY WORDS: Mangroves $\cdot$ Grapsid crabs $\cdot$ Copepods $\cdot$ Outwelling $\cdot$ Decomposition $\cdot$ Micro-POM • Estuarine food chains

Resale or republication not permitted without written consent of the publisher

\section{INTRODUCTION}

Past studies of the trophic ecology mangroves have focussed on the degree of export of productivity of mangroves in support of nearshore consumers, probably a result of their apparent large standing crop, and often also high productivity (Alongi 1998). Much effort has been spent on measuring flux of organic matter and nutrients from mangroves (Twilly 1988), but mangrove-nearshore exchange patterns are still obscure. An emerging picture suggests that organic matter export from stands of mangroves is both limited in quantity and spatial extent (Lee 1995), and some systems may even import organic matter (Alongi 1998). Further, the trophic value of outwelled mangrove matter to nearshore consumers is debatable, as most studies employing chemical tracers such as stable isotopes of carbon, nitrogen and sulphur record little resemblance between consumers and mangrove signatures (Rodelli et al. 1984, Newell et al. 1995, Lee 2000).

Ground-dwelling grapsid crabs have been reported to be the main consumers of fresh mangrove litter, particularly in Indo-Pacific systems (Robertson et al. 1992, Lee 1998). Fresh mangrove litter has low nutrient $(\mathrm{C} / \mathrm{N}$ 
ratio $>50$ ) but high feeding deterrent (e.g. soluble tannins) content, making it an unattractive staple food item (Wolcott \& O'Connor 1992). Some grapsid crab species prefer leaf litter with specific $\mathrm{C} / \mathrm{N}$ ratios (e.g. Lee 1993), while others feed indiscriminately (Micheli 1993). Grapsid crabs nevertheless can consume large percentages of fresh mangrove litter and help retain mangrove productivity within the forest. While it is still unclear how the crabs can benefit from such a poor diet, one of the little studied areas is the fate of the mangrove organic matter consumed and processed by the crabs. Acting as initial processors of mangrove leaf litter, grapsid crabs mediate significant physical, and potentially chemical and biological, changes to mangrove organic production. Ignorance of these changes makes a thorough evaluation of the trophic contribution of tropical mangroves difficult - the link to nearshore production may not be as direct as previously assumed (i.e. export of unconsumed and only minimally microbially enriched macro-detritus).

In this study, our aim is to gauge the impact of leaf litter processing by grapsids on the quality of this litter as food for macrofauna and zooplankton in nearshore waters. Our approach consisted of a number of field and laboratory experiments, each testing part of the potential trophic link: (1) a litter decomposition experiment investigating the physical, chemical and biological changes associated with crab-processed and naturally senescent leaf litter; (2) a laboratory experiment comparing the survivorship of 2 common species of nearshore copepods fed diets of an unicellular alga or crab-processed mangrove leaf litter; and (3) an estimation of the contribution of crab-processed mangrove leaf litter to the micro-particulate organic matter (micro-POM) pool of mangrove estuaries in SE Queensland, Australia.

\section{MATERIALS AND METHODS}

All sampling were conducted in Moreton Bay, SE Queensland, where extensive mangrove forests dominated by Avicennia marina and, to a lesser extent, Rhizophora stylosa and Aegiceras corniculatum exist. Fig. 1 shows the sampling and experimental locations mentioned in the following subsections. Though not supporting grapsid crab densities comparable to tropical NE Queensland, significant populations of grapsid crabs still live in the local mangroves, with Parasesarma erythodactyla being one of the dominant species.

Transformation of mangrove litter without crab processing. Transformation of mangrove litter relevant to their trophic value (e.g. C/N ratio, surface bacteria density) was compared between pathways with and without grapsid crab involvement. Strictly speaking, this is not a direct comparison, as experimental conditions for the 2 pathways cannot be easily standardised. Freshly senescent leaf litter of Rhizophora stylosa and Avicennia marina was collected from Jabiru Island on the Gold Coast by lightly plucking the petiole of yellow leaves. Leaves that would not detach easily were not included in the sample. The wet weight of the leaves was then recorded to the nearest $0.01 \mathrm{~g}$ in the laboratory, before they were individually put into nylon bags of $2 \mathrm{~mm}$ mesh. A separate large sample of the leaves of each species was dried at $80^{\circ} \mathrm{C}$ for $48 \mathrm{~h}$ to obtain a regression relationship between wet and dry weight and in order to estimate the initial dry weight of the experimental leaves.

The litterbags were returned to Jabiru Island shortly after the measurements, and placed in the area (midintertidal, $\sim 1.7 \mathrm{~m}$ above extreme low water spring) where they were first collected. The bags were laid flat on the sediment surface of the mangrove forest, and pneumatophores were cut at sediment level where necessary to ensure regular inundation. Twenty leaves of each species were retrieved at each of the 5 sampling dates, namely, 14, 28, 56, 112 and $168 \mathrm{~d}$ after the beginning of the experiment.

The leaf fragments were collected and briefly washed in de-ionised water in the laboratory and the dry weight recorded to indicate the rate of organic matter

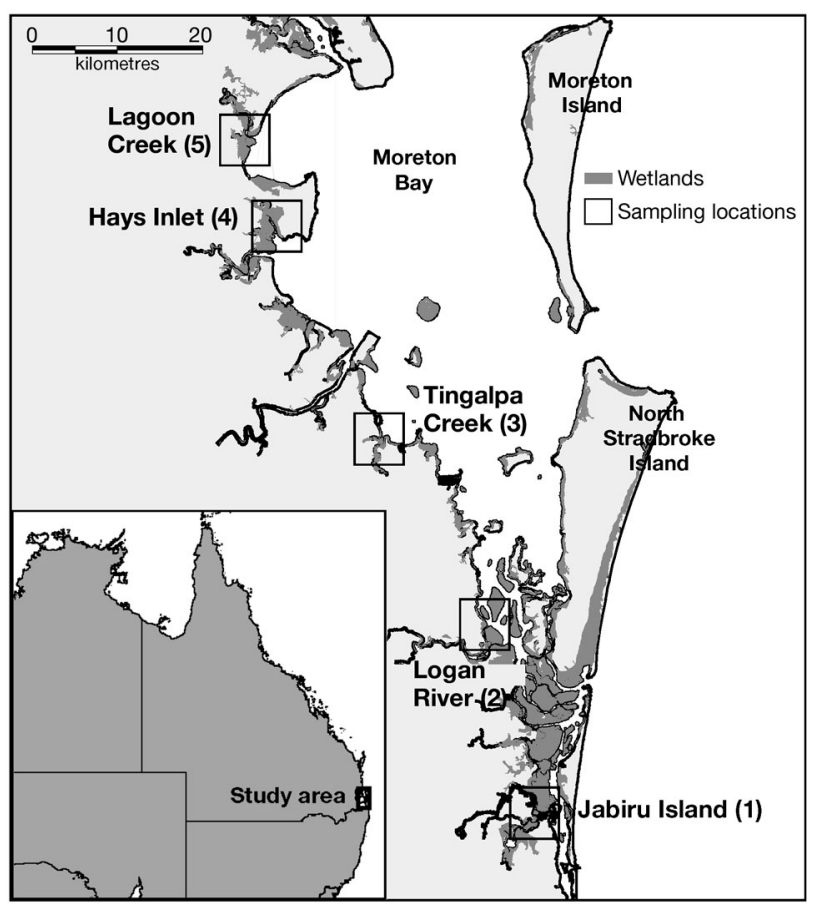

Fig. 1. Moreton Bay, SE Queensland, Australia, showing locations mentioned in the text 
loss over time. Five leaves from each combination of type and collection date were set aside for measuring transformations that may determine the trophic value of the material. Leaf squares of $1 \mathrm{~cm}^{2}$ were randomly removed from the decomposing leaves in the laboratory and preserved in $3 \%$ glutaldehyde for $2 \mathrm{~h}$, followed by dehydration and the enumeration of bacteria by scanning electron microscopy. Counting of surface bacteria on each leaf disc was made on 20 randomly located spots at 5400× magnification and density was calculated as number per $0.225 \mathrm{~mm}^{2}$. Trials using the acridine orange method in estimating bacteria density returned significantly lower densities compared with the SEM approach (authors' unpubl. data), and the latter method was therefore adopted as an indication of the abundance of bacteria colonising the decomposing mangrove material.

The remaining material from each of the leaves was then dried at $60^{\circ} \mathrm{C}$ for $48 \mathrm{~h}$ and ground for analysis of their stable isotopic signatures for carbon and nitrogen $\left(\delta^{13} \mathrm{C}\right.$ and $\left.\delta^{15} \mathrm{~N}\right)$ and carbon and nitrogen contents.

Transformation of mangrove litter with crabprocessing. The transformations undergone by mangrove organic matter consumed by crabs were studied in the laboratory, because differences in the nature of the material (e.g. size of detritus fragments) made it difficult to conduct parallel comparisons in the field. Due to the limitation in available experimental space, only Avicennia marina, the local dominant species, was studied. Individuals of the grapsid crab Parasesarma erythodactyla were collected from the mangrove forest on Jabiru Island. The gut of the crabs were purged by starving them for $48 \mathrm{~h}$ and noting that the crabs had finished defaecating before the experiment began. Each crab was kept in a small container in a temperature-controlled room at $26^{\circ} \mathrm{C}$ and a light:dark cycle of 12:12 h. In order to minimise contamination, no sediment was provided in the containers but enough water $(<1 \mathrm{~cm})$ was provided to allow the crab to be kept moist for respiration and, occasionally, moulting. The crabs were provided freshly senescent $A$. marina leaf litter ad libitum, typically at about 1 leaf every $48 \mathrm{~h}$. Faecal pellets produced by the crabs were collected daily, and production by individual crabs was kept separate in smaller containers in a small $(<5 \mathrm{ml})$ volume of seawater, also collected from Jabiru Island. In order to avoid contamination by external suspended particulate organic matter, water used in the experiment was filtered through Whatman No. 1 filter paper beforehand, which removed the particulates but retained the microbes present. The containers with the faecal material were kept on a shelf in a temperaturecontrolled room and covered with a $2 \mathrm{~mm}$ nylon mesh to allow ventilation while minimising contamination due to entry of foreign materials. Samples of the faecal material were collected every $3 \mathrm{~d}$ during the $3 \mathrm{wk}$ incubation period. Similar to the whole leaf experiment, sub-samples from each container were collected for SEM analysis. The remaining samples were dried at $60^{\circ} \mathrm{C}$ and their stable isotope signatures and carbon and nitrogen contents were measured.

Size of leaf fragments in the faecal pellets was measured using light microscopy as described below. Three pellets produced by each of 20 crabs were collected fresh and the contents dispersed in a petri dish for measurement. Thirty fragments were randomly selected from the dispersed contents, and their maximum dimension measured under low power (40 to 100×) using a calibrated ocular micrometer.

SEM measurements were made on 5 separate fields (replicates) for each of the faecal samples, using a Hitachi electron microscope. Counting of bacteria was performed on photographic quadrats at 3000× magnification, each field covering an area of $\sim 375 \mu^{2}$. The average diameter of leaf fragments in crab faeces was $\sim 200 \mu \mathrm{m}$, providing enough area for independent bacteria counting on the fragments using the same protocol as in the whole leaf samples.

The stable isotope signature of the litter samples with and without crab processing was measured using a continuous-flow isotope-ratio mass spectrometer, with the appropriate standards. Standards were introduced at regular intervals to provide quality control as well as to give an indication of the level of precision, which was maintained at $\pm 1 \%$ for both $\mathrm{C}$ and $\mathrm{N}$. The measurements also provide values of $\% \mathrm{C}$ and $\% \mathrm{~N}$ for the samples, from which the $\mathrm{C} / \mathrm{N}$ ratio is calculated.

The nature of suspended particulate organic matter in mangrove waterways. With the chemical characterisation information available, it was possible to assess the prevalence of crab-processed mangrove organic matter in waterways adjacent to mangrove forests. Particulate organic matter was collected at 3 stations: at the interface with the mangrove forest, the mouth of the mangrove creek, and the centre of the main channel along 5 mangrove waterways in southern Moreton Bay, where extensive mangrove stands dominated by Avicennia marina occur (see Fig. 1). These positions with different degrees of proximity to the mangroves would provide a gradient of the availability of mangrove organic matter, in fine particulate form. At each location, up to 10 replicate samples were collected by filtering about $50 \mathrm{l}$ of water through pre-weighed and pre-combusted GF/C papers. Filters were wrapped in individual pre-combusted aluminium foils and dried at $60^{\circ} \mathrm{C}$ for $48 \mathrm{~h}$ before their stable isotope signatures were measured as described above.

The fate of crab-processed mangrove organic matter. Possible trophic linkages originating from crabprocessed mangrove organic matter were studied by 
performing laboratory-rearing experiments. Lee (1997) demonstrated that small invertebrates such as the amphipod Parhyella sp. could beneficially utilise crab faecal material and survived significantly longer periods of time in the laboratory than individuals maintained on a mangrove litter diet. In this experiment, the potential trophic value of resuspended crab-processed mangrove organic matter was evaluated using 2 species of copepods common in local waterways within 2 to $3 \mathrm{~km}$ from mangrove forests.

Feeding experiments were conducted on 2 species of common nearshore copepods, namely, Temora turbinata (Calanoida) and Oithona rigida (Cyclopoida). Since the 2 copepod species occur at different seasons, the 2 experiments were conducted at different times. Samples of $T$. turbinata and $O$. rigida were obtained from the Broadwater, southern Moreton Bay, using a $80 \mu \mathrm{m}$ plankton net. The copepods were identified and sorted in the laboratory with the help of a stereomicroscope, and male and female animals were identified. Individuals were (1:2 F:M) transferred to $500 \mathrm{ml}$ Schott bottles, which were maintained at $26^{\circ} \mathrm{C}$ in a constant temperature room with a 12:12 h light:dark regime. Gentle aeration was provided to provide oxygen as well as to keep the food particles in suspension in the containers. Locations of the bottles for the 4 treatments (details below) were randomised so as to minimise the impact of local environmental conditions on the behaviour of the copepods.

Four treatments of food were provided, with 13 replicates for Temora turbinata (each with 200 individuals) and 5 for Oithona rigida (each with 50 individuals) for each treatment. In one treatment, no food was provided. The 3 food treatments were, respectively, (1) crab faecal material conditioned at $26^{\circ} \mathrm{C}$ for $>2 \mathrm{~d}$ (F treatment); (2) the unicellular algae Nannochloropsis sp. (A treatment); (3) a combination of crab faecal material and Nannochloropsis (M treatment). Nannochloropsis culture was obtained from the Bribie Island Aquaculture Research Station of the Department of Primary Industry and Fisheries.

Copepods are known to respond to $\mathrm{N}$ limitation. The total $\mathrm{N}$ content of the initial ration was therefore standardised with knowledge of the $\mathrm{N}$ concentration of the food items. New food was not provided unless there was a visible depletion of material in the containers.

Survival and population density of the copepods in the 4 treatments were monitored every $2 \mathrm{~d}$. Both species of copepods are positively phototaxic. The number of copepods in the containers was estimated by shining a light on one end of the container and counting of the number of individuals present. This enumeration method was necessary as other methods (e.g. homogenising the culture and sub-sampling) would inflict significant disturbance to the population. This method is also more accurate in determining the maximum survival period of the animals.

In order to ascertain the relationship between survivorship and the food provided, the $\delta^{13} \mathrm{C}$ and $\delta^{15} \mathrm{~N}$ values of the food items and the copepods were determined. Pure samples of the 2 food items were measured using the procedure above, while copepods samples were collected from the experimental containers. Several independent samples were analysed by randomly pooling copepods from more than 1 container to provide enough samples for the stable isotope measurements. Copepod samples were mostly freshly dead specimens, usually with little gut contents.

Data analysis. Results of the field micro-POM stable isotope signatures were analysed by 2-way mixedmodel ANOVAs with replication; location was a random factor and proximity to mangroves (forest, edge and channel) was a fixed factor. A planned contrast was performed on the effect of proximity to mangroves on the various chemical characteristics of the microPOM.

Survival of the copepods in the feeding experiment was analysed by a repeated-measures ANOVA, with food (4 levels, fixed factor) as the between-subject factor and days of experiment as the repeated measures (within-subject) factor. Data collected on all sampling days except Day 0 (collected every $2 \mathrm{~d}$ for 14 and $24 \mathrm{~d}$, respectively, for the Temora and Oithona experiments) were included in the analysis. This test assesses the difference in pattern of survivorship amongst the 4 food treatments over the experimental period. Where significant effect was detected in the ANOVA and there was no significant food-day interaction, comparison amongst the 4 food treatments was performed using Tukey's test. All statistical analyses were conducted using SPSS.

\section{RESULTS}

\section{Transformation of whole and crab-processed mangrove litter}

Changes in ash-free dry weight (AFDW) of whole leaves of both mangrove species followed almost linear decrease over the $168 \mathrm{~d}$ period (Fig. 2A). Rate of AFDW loss was best described by the linear rather than negative exponential model, and was significantly faster in Avicennia marina than in Rhizophora stylosa, with the final AFDW remaining for 2 species at $16.8 \pm 7.7 \%$ and $51.7 \pm 13.4 \%$ (all values are mean $\pm 1 \mathrm{SD}$ unless otherwise indicated), respectively. The senescent mangrove leaves were poor in $\mathrm{N}$ : the $\% \mathrm{~N}$ was $0.65 \pm 0.09$ for $A$. marina and $0.41 \pm 0.08$ for $R$. stylosa. The initial $\mathrm{C} / \mathrm{N}$ ratio of litter from $A$. marine was $70.4 \pm 8.9$ and from $R$. 

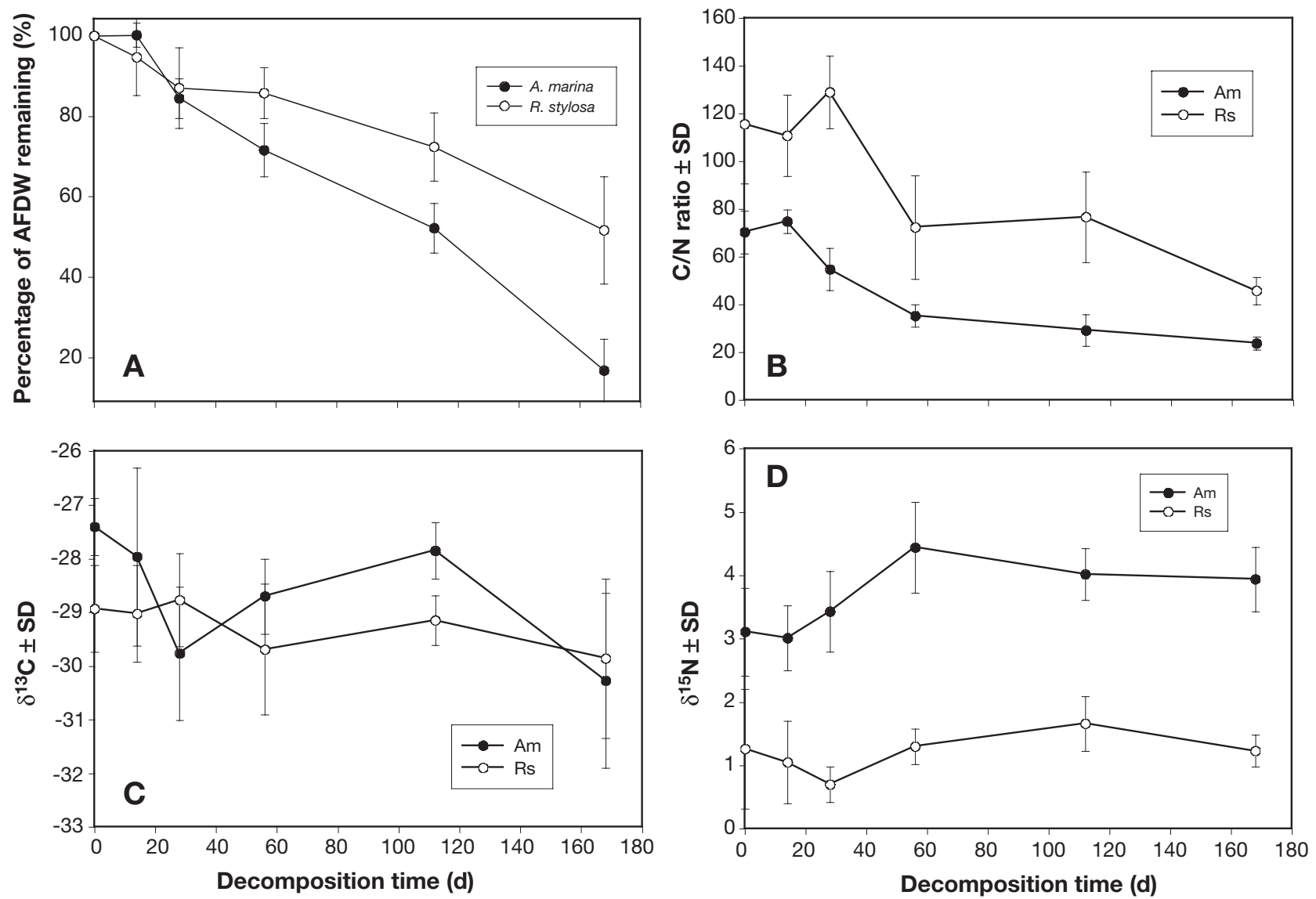

Fig. 2. Rhizophora stylosa and Avicennia marina. Chemical and biological changes decomposing whole-leaf litter of (A) \% ash-free dry weight (AFDW) remaining; (B) $\mathrm{C} / \mathrm{N}$ ratio; (C) $\delta^{13} \mathrm{C}(\%)$; and (D) $\delta^{15} \mathrm{~N}(\%)$. All values are mean $\pm 1 \mathrm{SD}$

stylosa, $115.6 \pm 24.9$. Change in the atomic $\mathrm{C} / \mathrm{N}$ ratio (Fig. 2B) of decomposing litter was rapid in the period between 20 to $60 \mathrm{~d}$ for both species, with the final values after $168 \mathrm{~d}$ at $45.8 \pm 5.1$ for $R$. stylosa and $23.8 \pm 2.8$ for A. marina.

Change in the stable isotope signature of litterbag leaves did not follow distinct trends. $\delta^{13} \mathrm{C}$ varied widely over the decomposition period in both species, and there was no significant temporal trend $(p>0.05$ for $r$ in both cases, Fig. 2C,D). Similarly, there was no significant trend in $\delta^{15} \mathrm{~N}$ for either species, with values fluctuating around +1 and $+4 \%$ ofor Rhizophora stylosa and Avicennia marina, respectively.

Surface bacteria density of whole-leaf samples increased rapidly with time (Fig. 3A), linearly for both species in the first $56 \mathrm{~d}$ of experiment. The density of bacteria was significantly higher in Avicennia marina after $56 \mathrm{~d}$. Bacterial density of decaying crab faecal material, however, conformed to a tight sigmoidal trajectory $\left(\mathrm{r}^{2}=0.86, \mathrm{n}=15, \mathrm{p}<0.0001\right)$ (Fig. 3B), increasing by 8 times over the experimental period and peaking at Day 20.
Feeding by Parasesarma erythodactyla reduced whole mangrove leaf litter to fragments with a mean diameter of $219 \pm 93 \mu \mathrm{m}$ (mean $\pm 1 \mathrm{SD}$ ). Rate of decomposition was linear for the crab-processed mangrove leaf litter with a half-life of $90.1 \mathrm{~d}$ (linear regression: faecal material remaining $=90.1-0.45 \mathrm{~d}_{i} \mathrm{r}^{2}=0.45, \mathrm{n}=15, \mathrm{p}=$ 0.003). Nitrogen content of the faecal material increased slightly but was not correlated with bacteria colonization ( $\mathrm{r}=0.45, \mathrm{n}=15, \mathrm{p}=0.08$ ) while carbon content decreased linearly $\left(\mathrm{r}^{2}=0.09, \mathrm{n}=15, \mathrm{p}=0.25\right)$. Change in $\delta^{15} \mathrm{~N}$ with time was significant $(\mathrm{p}=0.0003)$ and gradually depleted from an initial average of +5 to $+1.8 \%$ (Fig. 4A). This trend in $\delta^{15} \mathrm{~N}$ with time was significantly negatively correlated $(\mathrm{r}=-0.73, \mathrm{n}=15$, $\mathrm{p}=0.003$ ) to bacteria density. $\delta^{13} \mathrm{C}$ signature remained constant at around $-28 \%$ (Fig. 4B) over the same period. $\mathrm{C} / \mathrm{N}$ ratio decreased significantly (from 30 to 21 ) indicating increasing nutritional value in the crabprocessed mangrove material with time (Fig. 4C). Decrease in $\mathrm{C} / \mathrm{N}$ ratio was strongly correlated with increase in bacteria density $(r=-0.73, n=15, p=0.003)$. 

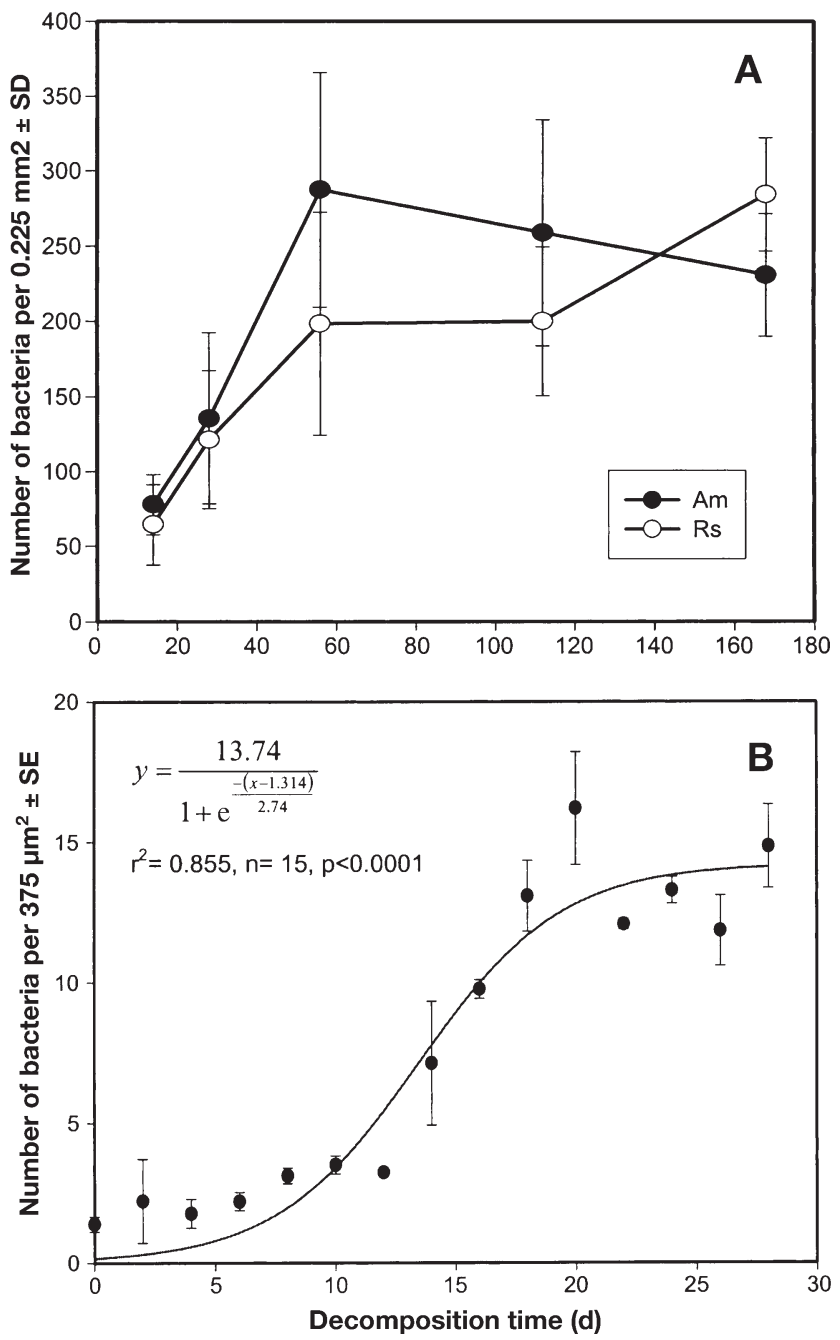

Fig. 3. Change in bacteria density on (A) whole leaf litter of Rhizophora stylosa and Avicennia marina; and (B) Parasesarma erythodactyla faecal material, with decomposition time. Data points are means of 5 replicates (whole leaf litter) or triplicates (faecal material)

\section{Nature of suspended particulate organic matter in mangrove waterways}

There was generally no significant interaction between the factors of location and site (position in waterway) in micro-POM chemical composition, except for \% organic matter (Table 1). All measured parameters of micro-POM composition showed a significant difference $(p<0.001)$ between sampling locations. Within each location the nature of micro-POM showed no significant differences for most of the parameters measured. $\delta^{13} \mathrm{C}$ signatures, however, varied significantly with proximity to mangrove forest (2-way mixed model ANOVA, $F=12.3$, df = 2, 13.9, p < 0.001), with a significant contrast $(p=0.031)$ between the forest $(F)$ and
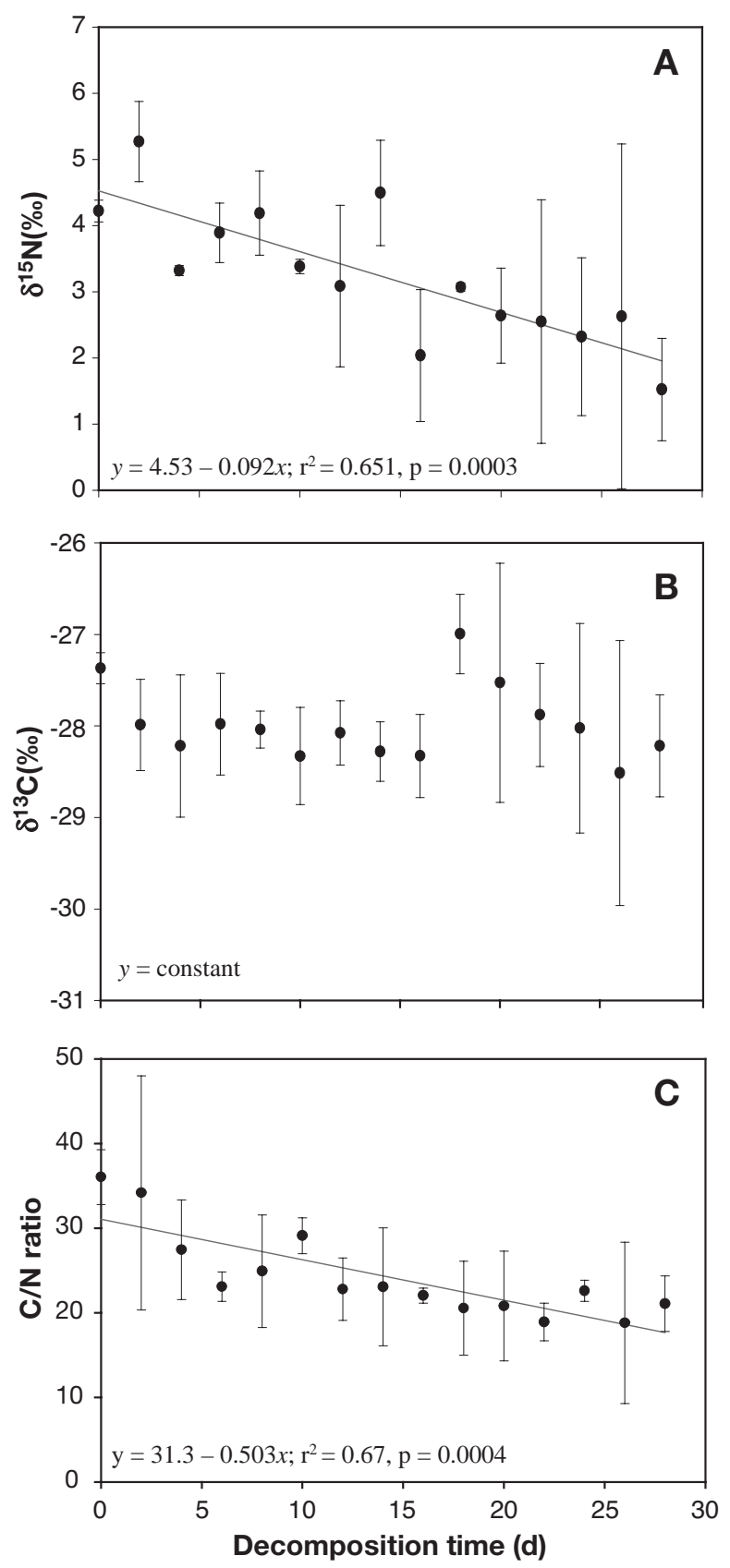

Fig. 4. Parasesarma erythodactyla. Change in (A) $\delta^{15} \mathrm{~N}$; (B) $\delta^{13} \mathrm{C}$ and (C) $\mathrm{C} / \mathrm{N}$ ratio values of faecal material with decomposition time. Each data point is the average of 3 independent replicates $( \pm 1 \mathrm{SD} n=15$ for all parameters

channel (C) positions. Micro-POM $\delta^{13} \mathrm{C}$ values from Jabiru Island and Tingalpa Creek were most depleted and had the closest values to the fresh crab-processed mangrove material $\delta^{13} \mathrm{C}$ value. $\delta^{15} \mathrm{~N}$ differences to the $\delta^{15} \mathrm{~N}$ faecal material standard for all locations were substantially greater than differences to $\delta^{13} \mathrm{C}$ and $\mathrm{C} / \mathrm{N}$ ratio for all locations. Organic content of micro-POM showed 
Table 1. Mean $( \pm 1 \mathrm{SD})$ values of the chemical measurements of micro-POM. Each mean is the average from different numbers of replicates. The results of univariate mixed-model ANOVAs including a planned contrast for difference between channel and forest sites are given. OM: organic matter; NS: not significant; F: forest; E: edge; $\mathrm{C}$ : channel

\begin{tabular}{|c|c|c|c|c|c|c|c|}
\hline & & $\delta^{15} \mathrm{~N}(\% \circ)$ & $\delta^{13} \mathrm{C}(\%)$ & $\% \mathrm{C}$ & $\% \mathrm{~N}$ & $\mathrm{C} / \mathrm{N}$ & $\% \mathrm{OM}$ \\
\hline Jabiru & $\mathrm{F}$ & $4.6 \pm 2.3$ & $-25.5 \pm 1.1$ & $1.3 \pm 0.3$ & $0.1 \pm 0.03$ & $8.2 \pm 1.5$ & $15.5 \pm 1.8$ \\
\hline \multirow[t]{2}{*}{ Island } & $\mathrm{E}$ & $4.8 \pm 3.8$ & $-25.3 \pm 1.0$ & $1.3 \pm 0.3$ & $0.2 \pm 0.03$ & $8.0 \pm 0.9$ & $14.3 \pm 1.1$ \\
\hline & $\mathrm{C}$ & $5.1 \pm 1.2$ & $-24.9 \pm 1.0$ & $0.1 \pm 0.3$ & $0.1 \pm 0.04$ & $6.8 \pm 0.6$ & $14.5 \pm 1.4$ \\
\hline Logan & $\mathrm{F}$ & $6.2 \pm 1.6$ & $-22.6 \pm 0.9$ & $1.2 \pm 0.27$ & $0.2 \pm 0.05$ & $8.1 \pm 1.4$ & $15.2 \pm 1.2$ \\
\hline \multirow[t]{2}{*}{ River } & $\mathrm{E}$ & $6.6 \pm 1.0$ & $-21.7 \pm 0.6$ & $1.2 \pm 0.1$ & $0.1 \pm 0.04$ & $9.0 \pm 3.5$ & $15.6 \pm 0.6$ \\
\hline & $\mathrm{C}$ & $4.9 \pm 3.0$ & $-21.5 \pm 0.2$ & $1.2 \pm 0.1$ & $0.2 \pm 0.08$ & $7.8 \pm 2.7$ & $13.5 \pm 2.7$ \\
\hline Tingalpa & $\mathrm{F}$ & $11.6 \pm 1.1$ & $-25.6 \pm 0.8$ & $1.8 \pm 0.4$ & $0.2 \pm 0.03$ & $8.0 \pm 2.0$ & $15.8 \pm 1.1$ \\
\hline \multirow[t]{2}{*}{ Creek } & $\mathrm{E}$ & $11.6 \pm 2.2$ & $-24.9 \pm 1.2$ & $1.7 \pm 0.9$ & $0.2 \pm 0.06$ & $8.7 \pm 1.4$ & $16.8 \pm 2.3$ \\
\hline & $\mathrm{C}$ & $12.0 \pm 1.8$ & $-24.8 \pm 1.8$ & $2.3 \pm 0.7$ & $0.2 \pm 0.03$ & $9.0 \pm 2.9$ & $18.2 \pm 2.1$ \\
\hline Hays & $\mathrm{F}$ & $14.1 \pm 4.7$ & $-24.6 \pm 0.5$ & $2.5 \pm 0.5$ & $0.4 \pm 0.09$ & $6.5 \pm 0.4$ & $22.6 \pm 2.5$ \\
\hline \multirow[t]{2}{*}{ Inlet } & $\mathrm{E}$ & $14.6 \pm 3.2$ & $-23.4 \pm 0.6$ & $2.5 \pm 0.5$ & $0.3 \pm 0.06$ & $6.5 \pm 0.2$ & $21.8 \pm 1.7$ \\
\hline & $\mathrm{C}$ & $16.7 \pm 3.6$ & $-23.2 \pm 0.3$ & $2.4 \pm 0.4$ & $0.4 \pm 0.05$ & $6.6 \pm 1.2$ & $21.4 \pm 1.1$ \\
\hline Lagoon & $\mathrm{F}$ & $8.6 \pm 2.3$ & $-19.9 \pm 2.2$ & $0.3 \pm 0.3$ & $0.1 \pm 0.03$ & $4.4 \pm 1.9$ & $18.9 \pm 1.7$ \\
\hline \multirow[t]{2}{*}{ Creek } & $\mathrm{E}$ & $7.7 \pm 0.8$ & $-18.7 \pm 1.8$ & $0.3 \pm 0.1$ & $0.1 \pm 0.03$ & $4.0 \pm 0.8$ & $17.3 \pm 1.2$ \\
\hline & $\mathrm{C}$ & $8.5 \pm 0.4$ & $-18.7 \pm 4.3$ & $0.5 \pm 0.1$ & $0.1 \pm 0.01$ & $3.4 \pm 0.7$ & $16.8 \pm 1.5$ \\
\hline \multirow[t]{3}{*}{ Location (L) } & $F$-value & 20.7 & 198.8 & 40.2 & 25.7 & 33.9 & 14.3 \\
\hline & $\mathrm{df}$ & $4,8.2$ & $4,8.7$ & $4,8.1$ & $4,8.1$ & $4,8.1$ & $4,8.0$ \\
\hline & $\mathrm{p}$ & $<0.001$ & $<0.001$ & $<0.001$ & $<0.001$ & $<0.001$ & $<0.001$ \\
\hline \multirow{4}{*}{$\begin{array}{l}\text { Proximity to } \\
\text { mangrove } \\
\text { forest }(\mathrm{P})\end{array}$} & $F$-value & 0.57 & 12.3 & 0.18 & 0.44 & 0.68 & 0.78 \\
\hline & $\mathrm{df}$ & $2,9.5$ & $2,13.9$ & $2,8.9$ & $2,8.7$ & $2,8.5$ & $2,8.1$ \\
\hline & $\mathrm{p}$ & 0.584 & 0.001 & 0.842 & 0.657 & 0.531 & 0.492 \\
\hline & Contrast $p$ & NS & 0.031 & NS & NS & NS & Not tested \\
\hline \multirow[t]{2}{*}{$\mathrm{L} \times \mathrm{P}$ interaction } & $F$-value & 0.92 & 0.24 & 1.24 & 2.16 & 1.97 & 3.9 \\
\hline & $\mathrm{p}$ & NS & NS & NS & NS & NS & $<0.001$ \\
\hline
\end{tabular}

a general trend of highest percentage within forest sites followed by edge and then channel sites for all locations except Tingalpa Creek, which showed the opposite trajectory (Table 1), which was probably responsible for the significant location $\times$ proximity interaction.

\section{Value of crab-processed mangrove organic matter to pelagic copepods}

Survivorship of Temora turbinata differed significantly between treatments over time (repeated-measures ANOVA, $F=94.2, \mathrm{df}=3,48 ; \mathrm{p}<0.001$ ) and was highest for $T$. turbinata individuals in the combination of crab faecal material and Nannochloropsis (M treatment). and in the crab faecal material (F) treatment (Fig. 5A). T. turbinata in the $\mathrm{M}$ and $\mathrm{F}$ treatments suffered only $45 \%$ and $30 \%$ mortality respectively, during the first $6 \mathrm{~d}$. All individuals in the no-food control died within $4 \mathrm{~d}$. Copepods reared on the alga (Nannochloropsis sp.)-only (A) diet also suffered low survivorship with $90 \%$ mortality by Day 4 .

Oithona rigida survivorship had a similar pattern to Temora turbinata with significantly higher survivorship in the $\mathrm{M}$ diet followed by the $\mathrm{F}$ diet (repeated- measures ANOVA, $F=10.1, \mathrm{df}=3,15 ; \mathrm{p}=0.001$; one of the no-food treatment flasks in the Oithona experiment has been excluded from the comparison because of an experimental error affecting copepod survivorship), but the length of experiment was substantially longer (25 d survivorship for $O$. rigida as opposed to $12 \mathrm{~d}$ for T. turbinata) (Fig. 5B). O. rigida reared on Nannochloropsis sp. had $80 \%$ mortality by Day 2, with $100 \%$ mortality by Day 20. Analysis of the change in survivorship with time for both experiments indicated a significant treatment by time interaction effect $(p<$ 0.001) for both copepod species.

Comparison of Temora turbinata and Oithona rigida isotopic signatures and the signatures of their respective diets suggests best survival was attained by those copepods with crab-processsed material in their diets. T. turbinata copepods in the $\mathrm{M}$ treatment had the closest $\delta^{13} \mathrm{C}$ signatures to their diet (difference in $\delta^{13} \mathrm{C}=$ $1.32 \%$ ) and similar differences $\left(0.80 \%\right.$ o in $\delta^{15} \mathrm{~N}$ signature to their diet compared to T. turbinata individuals in the faecal only treatment $(0.58 \%)$ (Fig. 6A). Difference in $\delta^{15} \mathrm{~N}$ between copepod and diet in the Nannochloropsis sp. only treatment was substantially larger $\left(4.56 \%\right.$ ), but with closer $\delta^{13} \mathrm{C}$ values for $T$. turbinata. $O$. rigida copepods in the $\mathrm{F}$ treatment had a difference of 

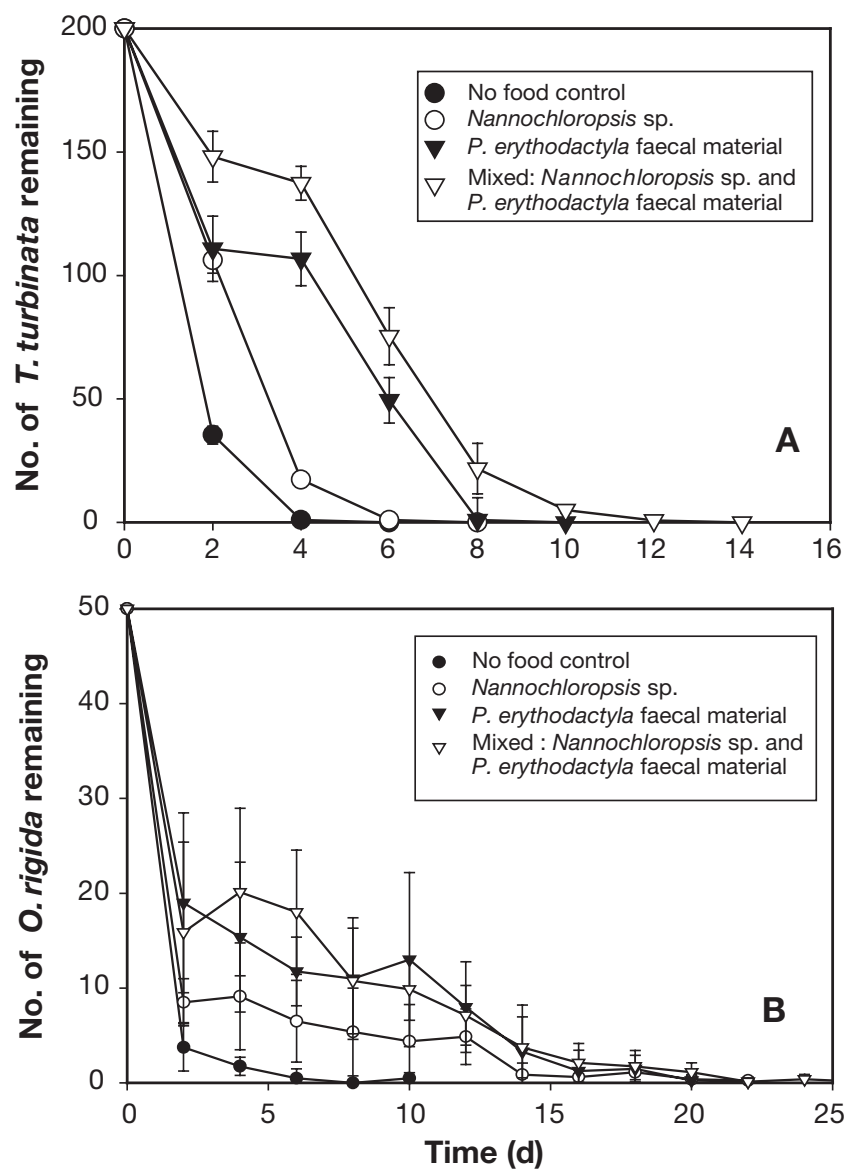

Fig. 5. Change in survivorship with time in cultures of (A) Temora turbinata and (B) Oithona rigida, fed the 4 diets in the feeding experiments. Each data point is the average of 13 replicates for $T$. turbinata and 5 replicates for $O$. rigida, $\pm 1 \mathrm{SE}$

$1 \%$ to the $\delta^{13} \mathrm{C}$ value of their food source and, $1.2 \%$ for those in the $\mathrm{M}$ treatment. Difference in $\delta^{13} \mathrm{C}$ value for $O$. rigida in the A treatment was much larger at $4.2 \%$ (Fig. 6B). Evaluation of the relative contribution of alga and faeces in the $\mathrm{M}$ treatment using mixing model cal- culations indicated contributions from crab faeces of $77 \%$ for T. turbinata and $51 \%$ for O. rigida for nitrogen whereas dependence on crab-processed carbon was $66 \%$ T. turbinata and $74 \%$ for O. rigida (Table 2).

\section{DISCUSSION}

\section{Shredded leaf litter - alternative form of mangrove export?}

The results of this study suggest that leaf litter processed by crabs undergoes a significantly different trajectory compared with simple microbial decomposition. Crab consumption reduced whole-leaf litter into small particulates averaging $\sim 200 \mu \mathrm{m}$ in diameter after digestion, which then attracted significantly faster colonisation by bacteria and resulted in a rapid decline in the $\mathrm{C} / \mathrm{N}$ ratio. The significant decline in $\delta^{15} \mathrm{~N}$ of the aged crab faecal pellet material, approaching $+1 \%$ after $3 \mathrm{wk}$ further suggests that the decrease in $\mathrm{C} / \mathrm{N}$ ratio had resulted from addition of external (atmospheric) $\mathrm{N}$ from microbial $\mathrm{N}$-fixation (Goericke et al. 1994).

Past decomposition studies of mangrove and wetland vascular plant material suggest that the $\delta^{13} \mathrm{C}$ signature changes are negligible with decomposition (Zieman et al. 1984, Freudenthal et al. 2001). While the change in $\delta^{13} \mathrm{C}$ was insignificant and comparable to that in the whole-leaf litter bag experiment, crabprocessed litter underwent significantly faster chemical changes in $\mathrm{C} / \mathrm{N}$ ratio, 3 orders of magnitude higher bacterial density and significant depletion of $\delta^{15} \mathrm{~N}$ compared with whole-leaf litter. Addition of external $\mathrm{N}$ through microbial colonisation is thought to be a significant step in the transformation of vascular plant litter (White \& Howes 1994). The shredding action of grapsid crabs predisposes mangrove leaf litter to rapid microbial colonisation, effecting significant changes in litter quality favouring meio- and macrofaunal utilisa-

Table 2. Two-member mixing model solutions to the relative contribution of Nannochloropsis sp. (Alga) and Parasesarma erythodactyla faeces (Faeces) to the signature in Oithona rigida and Temora turbinata (Copepods) in the mixed-food (M) treatment of the feeding experiment

\begin{tabular}{|c|c|c|c|c|c|c|c|c|c|c|c|c|}
\hline & \multicolumn{6}{|c|}{ 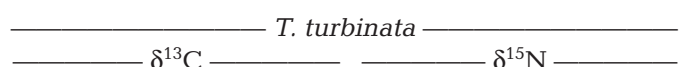 } & \multicolumn{6}{|c|}{$\longrightarrow$ O. rigida $-\delta^{13} \mathrm{C}-\delta^{15} \mathrm{~N}$} \\
\hline & $\overline{\text { Copepods }}$ & $\begin{array}{l}-\delta^{13} \mathrm{C}- \\
\text { Faeces }\end{array}$ & Alga & $\overline{\text { Copepods }}$ & $\begin{array}{l}\delta^{15} \mathrm{~N} \\
\text { Faeces }\end{array}$ & Alga & $\overline{\text { Copepods }}$ & $\begin{array}{l}\delta^{13} \mathrm{C} \\
\text { Faeces }\end{array}$ & Alga & $\overline{\text { Copepods }}$ & $\delta^{15} \mathrm{~N}$ & $\overline{\text { Alga }}$ \\
\hline Signature (\%o) & -26.21 & -27.44 & -23.87 & 4.76 & 5.96 & 0.68 & -29.50 & -27.45 & -35.11 & 8.7 & 14.05 & 3.05 \\
\hline (SD) & 2.4 & 0.1 & 1.38 & 1.32 & 0.40 & 0.22 & 0.06 & 0.43 & 0.12 & 0.09 & 0.2 & 0.27 \\
\hline Sample size & 5 & 5 & 5 & 5 & 5 & 5 & 5 & 3 & 3 & 5 & 3 & 3 \\
\hline Contribution $(\%) \pm$ & SE & $66 \pm 0.3$ & $34 \pm 0.3$ & & $77 \pm 0.1$ & $23 \pm 0.1$ & & $74 \pm 0.1$ & $26 \pm 0.1$ & & $51 \pm 0.02$ & $49 \pm 0.02$ \\
\hline $\begin{array}{l}95 \% \text { Confidence } \\
\text { limits (\%) }\end{array}$ & & $66-67$ & $34.4-35.1$ & & $76-78$ & $22-23.5$ & & $65-83$ & $17-35$ & & $52-50$ & $50-49$ \\
\hline
\end{tabular}




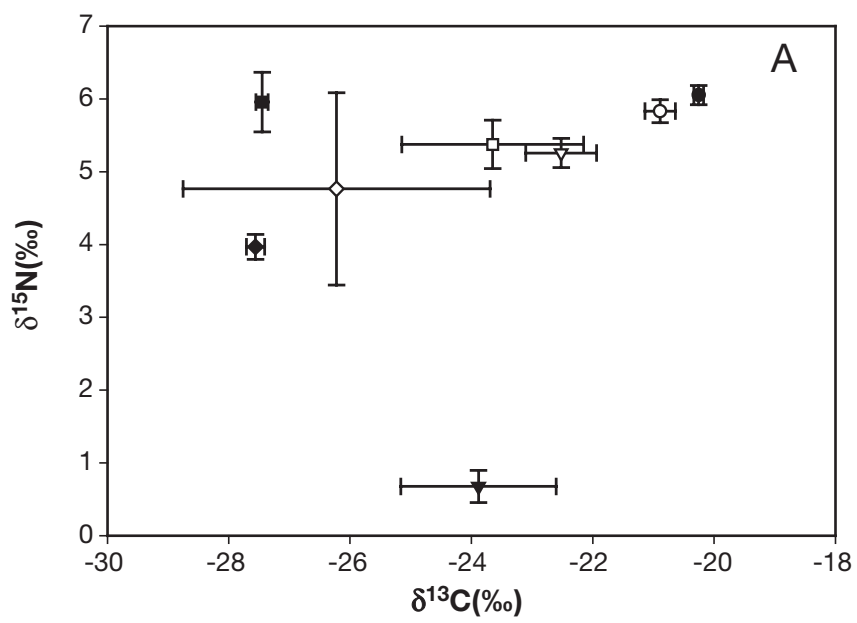

- T. turbinata from Gold Coast Seaway
T. turbinata: No food
Nannochloropsis sp.
$\nabla$ T. turbniata fed Nannochloropsis sp.
P. erythodactyla faeces
- T. turbinata fed $P$. erythodactyla faeces
$\diamond$ Mixture of Nannochloropsis and $P$. erythodactyla faeces
$\diamond T$. turbinata fed mixture of Nannochloropsis and $P$. erythodactyla faeces

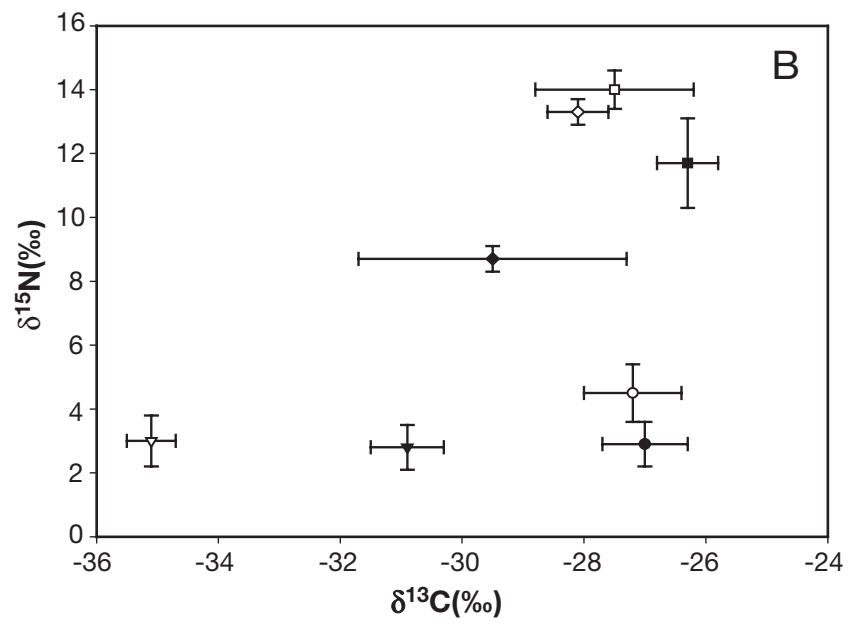

- O. rigida from Gold Coast Seaway - O. rigida control

$\checkmark$ O. rigida fed Nannochloropsis sp.

$\checkmark$ Nannochloropsis sp.

- 0 . rigida fed $P$. erythodactyla faeces

口 P. erythrodactyla faeces

O. rigida fed Nannochloropsis sp and $P$. erythodactyla faeces $\diamond$ Nannochloropsis sp. and $P$. erythodactyla faeces

Fig. 6. $\delta^{13} \mathrm{C}$ and $\delta^{15} \mathrm{~N}$ signatures of (A) Temora turbinata and (B) Oithona rigida, and their respective diets in the feeding experiments. Each data point is an average of 3 replicates for $T$. turbinata and 5 replicates for $O$. rigida, $\pm 1 \mathrm{SD}$

tion. While microbial processing of whole-leaf litter would also involve the same general changes, only a modest decline in $\mathrm{C} / \mathrm{N}$ ratio was noted for the litter bag experiment even after $>110 \mathrm{~d}$ for both Avicennia marina and Rhizophora stylosa leaf litter.

Significant microbial colonisation often results from addition of 'seed' bacteria from the gut of deposit-feeders or those present in the environment, or through regrowth of bacteria surviving through the digestive process (Plante et al. 1989, Plante \& Wilde 2001). Loss of feeding deterrents, such as phenolics, and dissolved organic matter, by leaching, a predominantly physical process, is also expected to be increased. Grapsid crabs generally egest about $70 \%$ of ingested leaf litter as faecal material (Lee 1997). The amount of raw mangrove leaf litter processed and then returned to the forest ecosystem in a form conducive to rapid microbial enrichment is therefore highly significant. Grapsid crabs thus play a role in mangroves similar to that of shredders in freshwater streams (Cummins 1974), a role mainly filled by insects (Wallace \& Webster 1996) but occasionally also by decapods where insects are rare (e.g. Usio 2000). Early views of stream ecosystem functioning asserted that shredder consumption of vascular plant litter only follows microbial enrichment (Webster \& Benfield 1986) but recent reviews conclude that such enrichment is not usually necessary and many shredders can consume seemingly nutritionally poor leaf material (Wallace \& Webster 1996). Shredders physically fragment large vascular plant material and return small particulate organic matter, either as a result of 'sloppy feeding' or faeces, and thus, promote leaf litter breakdown rates (Jonsson et al. 2001). Release of dissolved organic matter by leaching is also enhanced by shredder activity (Meyer \& O'Hop 1983, Wallace \& Webster 1996). Grapsid crabs actually fit most of the expectations of shredders in ecosystems driven by vascular plant detritus input, acting as initial processors of leaf litter of low nutritional quality, physically fragmenting the leaf litter and accelerating the enrichment process.

In freshwater systems, shredders provide the food for the 'gatherer' and 'filter-feeder' functional groups (Wallace \& Webster 1996), which, because of the unidirectional flow, are located downstream to the shredders. In tidal mangroves, flow of suspended materials is bi-directional at least over short time scales, e.g. over the course of a tidal cycle. It can be assumed, therefore, that a considerable portion of the shredded material processed by the crabs will be deposited on the forest floor. Grapsid crabs often spend more time feeding on surface sediments than feeding on whole leaf litter (Kwok 1999, Skov \& Hartnall 2002), and the enriched faecal material deposited on the sediment surface could be a valuable food resource to the crabs, possibly explaining how grapsid crabs can 
obtain enough nutrition from an apparently poor diet (the sesarmine crab Sesarma messa only assimilates $50 \%$ of the organic matter in fresh Rhizophora stylosa leaf litter, Lee 1997).

Herbivorous crabs face a number of challenges in consuming vascular plant litter (Wolcott \& O'Connor 1994), and mangrove grapsids encounter additional physiological difficulties in digesting leaf litter that is usually taken fresh, i.e. before microbial enrichment. The density of bacteria on decomposing mangrove leaf litter, as indicated in the litter bag experiment, is far too low to be beneficial to the crabs. Crab-processed litter, however, typically supports bacterial densities many times higher, with consequential changes in $\mathrm{C} / \mathrm{N}$ ratio, $\mathrm{N}$ content and $\delta^{15} \mathrm{~N}$. Bacteria density on crabprocessed leaf fragments was $\sim 30$ times higher after only $20 \mathrm{~d}$ compared with the peak density reached by whole leaf litter after about $60 \mathrm{~d}$. Despite the low nutritive value of fresh vascular plant litter, wetland crabs tend to maintain some consumption of plant material even when alternative, more nutritive, food sources are available (Buck et al. 2003).

By consuming some whole leaf litter, the crabs start an enrichment process that may generate more nutritive food through feeding on the surface sediment. This may represent a feeding mode similar to the 'gardening' behaviour of many deposit-feeders, providing a renewable food supply through the feeding activities of the organisms themselves (Rice \& Rhoads 1989, Levinton 1995). Coprophagy is probably an important aspect of the feeding strategy of grapsid crabs in tropical mangroves, while their shredding activities may also benefit other components of the estuary. The dependence of grapsid crabs on food resources other than fresh mangrove leaf litter is reflected by the commonly observed, more enriched $\delta^{13} \mathrm{C}(\sim-24 \%)$ signature relative to that of mangrove litter $(-27 \%$ ) (Rodelli et al. 1984, Lee 2000, Bouillon et al. 2002).

\section{Prevalence of mangrove micro-POM export in estuarine waterways}

A few studies have attempted to determine the origin of estuarine POM using chemical tracers (e.g. Thornton \& McManus 1994, Middleburg \& Nieuwenhuize 1998, Maksymowska et al. 2000, Riera et al. 2000). Thornton \& McManus (1994) used a combination of $\delta^{13} \mathrm{C}, \delta^{15} \mathrm{~N}$ and $\mathrm{C} / \mathrm{N}$ indicators to trace the origin of organic matter along the Tay Estuary in Scotland. These authors found that only $\delta^{13} \mathrm{C}$ seemed to give a reliable indication, as the other two were likely to be modified by diagenec processes.

Survey of the micro-POM at 5 mangrove-lined waterways in southern Moreton Bay suggested that the im- pact of mangrove export is often overridden by other including anthropogenic sources. Only the $\delta^{13} \mathrm{C}$ value of micro-POM was significantly influenced by proximity to mangrove forests. The $\delta^{13} \mathrm{C}$ of mangrove leaf litter changed little with crab or microbe-mediated decomposition (-27 to $-28 \%$ ). Values of all other including $\delta^{13} \mathrm{C}$ indicators varied significantly amongst waterways but not with proximity to mangrove forests. Even samples from the 'forest' locations (range -25.5 to $-19.9 \%$ ), which were expected to have the highest concentration of mangrove-derived POM, bore little direct correspondence to the $\delta^{13} \mathrm{C}$ signatures characteristic of either senescent or crab-processed mangrove leaf litter. Usually gradients in $\delta^{13} \mathrm{C}$ exist along the land-estuary continuum, with locations influenced by terrestrial sources demonstrating more depleted values (Canuel et al. 1995), and plankton material dominates shallow water bodies (Kennedy et al. 2004). The highly enriched $\delta^{15} \mathrm{~N}(\geq+9 \%$ ) signature of microPOM from all 5 waterways still fall within those expected of estuarine environments (Middelburg \& Nieuwenhuize 1998) but suggests relatively minor direct input from either whole or crab-processed mangrove leaf litter, but significant contribution from phytoplankton, microalgal $\left(\delta^{13} \mathrm{C}\right.$ range -18 to $-22 \%$ o or anthropogenic sources. Sewage $\mathrm{N}$ and animal excreta are known to have relatively enriched $\delta^{15} \mathrm{~N}(\sim+10 \%$, Macko \& Ostrom 1994) and anthropogenic dissolved inorganic nitrogen (DIN) resulting from wastewater input. The highly enriched $\delta^{15} \mathrm{~N}$ recorded throughout the waterways in southern Moreton Bay is probably a reflection of contamination from sewage and agricultural sources, diminishing the significance of mangrove-derived organic matter in the populous suburban embayment.

The $\mathrm{C} / \mathrm{N}$ ratio of the micro-POM $(\leq 9)$ is also too low to be of mangrove leaf litter origin. Decomposition of crab-processed leaf litter in the laboratory improved the $\mathrm{C} / \mathrm{N}$ ratio to $<20$ after $25 \mathrm{~d}$ but is still much higher than the observed value in the waterways. Low $\mathrm{C} / \mathrm{N}$ ratios are in fact typical of micro-POM in estuarine waterways and estuarine sediments (e.g. Canuel et al. 1995, Middelburg \& Nieuwenhuize 1998, Kennedy et al. 2004), reflecting the dominance of the seston by bacterioplankton, which have low $\mathrm{C} / \mathrm{N}$ ratios $(\sim 5$ to 7 , Kirchman 2000).

\section{Utilisation of crab-processed mangrove leaf litter by copepods}

The connection between mangrove production and nearshore secondary production has often been assessed based on estimates of tidal export of unprocessed leaf litter. Lee (1997), investigating the value of 
crab faecal material to a 'detritivorous' amphipod Parhyalella sp., suggested that crab-processed mangrove leaf litter could fuel a coprophagous food chain and contribute to nearshore secondary production in a different way.

In our present study, aged crab-processed mangrove material in the form of disintegrated crab faecal pellets supported higher survivorship in 1 common nearshore (Temora turbinata) and 1 common estuarine copepod species (Oithona rigida). Copepods are ubiquitous in mangrove waterways (Robertson \& Blaber 1992) and often form the main food source for larval and juvenile fish. Stable isotope analysis suggested that the copepods were utilising the mangrove-derived carbon for food. Contrary to findings on a congener ( $T$. longicornis, Klein Breteler et al. 2002), T. turbinata demonstrated depletion of $\delta^{13} \mathrm{C}$ in their body biomass compared with their food source, and the degree of fractionation seemed to be dependent on the food items. A $\delta^{13} \mathrm{C}$ of $-4 \%$ was recorded for the $\mathrm{F}$ treatment whereas it was less than $-2 \%$ in the $\mathrm{M}$ and $\mathrm{A}$ treatments. This pattern of $\mathrm{C}$ and $\mathrm{N}$ isotopic fractionation was also recorded for $O$. rigida, suggesting that isotopic fractionation patterns may be species- and fooddependent. This finding questions the application of simple and fixed fractionation values to analysing trophic relationships.

Reproduction in copepods is known to be dependent on food quality (e.g. Rey-Rassat et al. 2002). Although most of the treatments did not result in production of a second generation, it was observed that eggs and nauplius larvae were present in the treatments where crab faecal material was supplied. The high percentage of leaf litter that can be processed by grapsid crabs before tidal export in tropical mangroves (Lee 1998) implies that crab-processed mangrove leaf material can be a more important form of export supporting nearshore food chains.

Acknowledgements. This study was funded by a Large Grant from the Australian Research Council (00000284). We thank R. Li and C. Bartlett for field and laboratory assistance, and Bribie Island Aquaculture Research Station for the Nannochloropsis culture. Thank you to the numerous volunteers who assisted in fieldwork. Dr. D. McKinnon (Australian Institute of Marine Science) provided expertise on copepod culture, R. Diocares helped with stable isotope analyses and W. $\mathrm{Hu}$ assisted with SEM measurements. Dr. T. Meziane (Griffith University) and an anonymous referee provided constructive criticism to the manuscript.

\section{LITERATURE CITED}

Alongi DM (1998) Coastal ecological processes. CRC Press, Boca Raton

Bouillon S, Koedam N, Raman AV, Dehairs F (2002) Primary producers sustaining macro-invertebrate communities in intertidal mangrove forests. Oecologia 130:441-448
Buck TL, Breed GA, Pennings SC, Chase ME, Zimmer M, Carefoot TH (2003) Diet choice in an omnivorous saltmarsh crab: different food types, body size and habitat complexity. J Exp Mar Biol Ecol 292:103-116

Canuel EA, Cloern JE, Ringelberg DB, Guckert JB, Rau GH (1995) Molecular and isotopic tracers used to examine sources of organic matter and its incorporation into the food webs of San Francisco Bay. Limnol Oceanogr 40: $67-81$

Cummins KW (1974) Structure and function of stream ecosystems. Bioscience 24:631-641

Freudenthal T, Wagner T, Wenzhofer F, Zabel M, Wefer G (2001) Early diagenesis of organic matter from sediments of the eastern sub-tropical Atlantic: evidence from stable nitrogen and carbon isotopes. Geochem Cosmochim Acta 65:1795-1808

Goericke R, Montoya JP, Fry B (1994) Physiology of isotopic fractionation in algae and cyanobacteria. In: Lajtha $\mathrm{K}$, Michener RH (eds) Stable isotopes in ecology and environmental science. Blackwell Scientific Publications, Oxford, p 187-221

Jonsson M, Malmqvist B, Hoffsten PO (2001) Leaf litter breakdown rates in boreal streams: does shredder species richness matter? Freshwat Ecol 46:161-171

Kennedy H, Garcia E, Kennedy DP, Papadimitriou S, Duarte CM (2004) Organic carbon sources to SE Asian coastal sediments. Estuar Coast Shelf Sci 60:59-68

Kirchman DL (2000) Uptake and regeneration of inorganic nutrients by marine heterotrophic bacteria. In: Kirchman DL (ed) Microbial ecology of the oceans. Wiley-Liss, New York, p 261-288

Klein Breteler WCM, Grice K, Schouten S, Kloosterhuis T, Sinninghe Damsté JS (2002) Stable isotope fractionation in the marine copepod Temora longicornis: unexpectedly low $\delta^{13} \mathrm{C}$ value of faecal pellets. Mar Ecol Prog Ser 240: 195-204

Kwok PW (1999) Time activity budget of Perisesarma bidens and Parasesarma affinis (Brachyura: Sesarminae) at the Mai Po Marshes mangrove, Hong Kong. In: Lee SY (ed) The mangrove ecosystem of Deep Bay and the Mai Po marshes, Hong Kong. Hong Kong University Press, Hong Kong, p 137-151

Lee SY (1993) Leaf choice of the sesarmid crabs Chiromanthes bidens and $C$. affinis in a Hong Kong mangal. In: Morton B (ed) Proc Int Conf Marine Biology of Hong Kong and the South China Sea, University of Hong Kong, October 1990. Hong Kong University Press, Hong Kong, p 597-604

Lee SY (1995) Mangrove outwelling: a review. Hydrobiologia 295:203-212

Lee SY (1997) Potential trophic importance of the faecal material of the mangrove sesarmine crab Sesarma messa. Mar Ecol Prog Ser 159:275-284

Lee SY (1998) Ecological role of grapsid crabs in mangrove ecosystems: a review. Mar Freshw Res 49:335-343

Lee SY (2000) Carbon dynamics of Deep Bay, eastern Pearl River estuary, China. II. Trophic analysis using stable isotopes of carbon and nitrogen. Mar Ecol Prog Ser 205:1-10

Levinton JS (1995) Bioturbators as ecosystem engineers: control of the sediment fabric, inter-individual interactions, and material fluxes. In: Jones CG, Lawton JH (eds) Linking species and ecosystems. Chapman \& Hall, New York, p 29-44

Macko SA, Ostrom SE (1994) Pollution studies using stable isotopes. In: Lajtha K, Michener RH (eds) Stable isotopes in ecology and environmental science. Blackwell Scientific Publications, Oxford, p 45-62 
Maksymowska D, Richard P, Piekarek-Jankowska H, Riera P (2000) Chemical and isotopic composition of the organic matter sources in the Gulf of Gdansk (southern Baltic Sea). Estuar Coast Shelf Sci 51:585-598

Micheli F (1993) Feeding ecology of mangrove crabs in North Eastern Australia: mangrove litter consumption by Sesarma messa and Sesarma smithii. J Exp Mar Biol Ecol 171:164-186

Middelburg JJ, Nieuwenhuize J (1998) Carbon and nitrogen stable isotopes in suspended matter and sediments from the Schelde estuary. Mar Chem 60:217-225

Newell RIE, Marshall N, Sasekumar A, Chong VC (1995) Relative importance of benthic microalgae, phytoplankton, and mangroves as sources of nutrition for penaeid prawns and other coastal invertebrates from Malaysia. Mar Biol 123:595-606

Plante CJ, Wilde SB (2001) Bacterial recolonization of depositfeeder egesta: in situ regrowth or immigration? Limnol Oceanogr 46:1171-1181

Plante CJ, Jumas PA, Baross JA (1989) Rapid bacterial growth in the hind gut of a deposit feeder. Microb Ecol 18:29-44

Rey-Rassat C, Irigoien X, Harris R, Head R, Carlotti F (2002) Egg production rates of Calanus helgolandicus females reared in the laboratory: variability due to present and past feeding conditions. Mar Ecol Prog Ser 238:139-151

Rice DL, Rhoads DC (1989) Early diagensis of organic matter and the nutritional value of sediment. In: Lopez G, Taghon G (eds) Ecology of marine deposit feeders. SpringerVerlag, New York, p 59-97

Riera P, Stal LJ, Nieuwenhuize J (2000) Heavy $\delta^{15} \mathrm{~N}$ in intertidal benthic algae and invertebrates in the Scheldt estuary (the Netherlands): effect of river nitrogen inputs. Estuar Coast Shelf Sci 51:365-372

Robertson AI, Blaber SJM (1992) Plankton, epibenthos and fish communities. In: Robertson AI, Alongi DM (eds) Tropical mangrove ecosystems. American Geophysical Union, Washington, DC, p 173-224

Editorial responsibility: Otto Kinne (Editor-in-Chief), Oldendorf/Luhe, Germany
Robertson AI, Alongi DM, Boto KG (1992) Food chains and carbon fluxes. In: Robertson AI, Alongi DM (eds) Tropical mangrove ecosystems. American Geophysical Union, Washington, DC, p 293-326

Rodelli MR, Gearing JN, Gearing PJ, Marshall N, Sasekumar A (1984) Stable isotope ratio as tracer of mangrove carbon in Malaysian ecosystems. Oecologia 61:326-333

Skov M, Hartnall RG (2002) Paradoxical selective feeding on a low-nutrient diet: why do mangrove crabs eat leaves? Oecologia 131:1-7

Thornton SF, McManus J (1994) Application of organic carbon and nitrogen stable isotope and $\mathrm{C} / \mathrm{N}$ ratios as source indicators of organic matter provenance in estuarine systems: evidence from the Tay estuary, Scotland. Estuar Coast Shelf Sci 38:219-233

Twilley RR (1988) Coupling of mangroves to the productivity of estuarine and coastal waters. In: Jansson BO (ed) Coastal-offshore ecosystem interactions. Springer Verlag, Berlin, p 122-154

Usio N (2000) Effects of crayfish on leaf processing and invertebrate colonisation of leaves in a headwater stream: decoupling of a trophic cascade. Oecologia 124:608-614

Wallace JB, Webster JR (1996) The role of macroinvertebrates in stream ecosystem function. Ann Rev Entomol 41: 115-139

Webster JR, Benfield EF (1986) Vascular plant breakdown in freshwater ecosystems. Ann Rev Ecol Syst 17:567-594

White DS, Howes BL (1994) Nitrogen incorporation into decomposing litter of Spartina alterniflora. Limnol Oceanogr 39:133-140

Wolcott DL, O'Connor NJ (1992) Herbivory in crabs: adaptations and ecological considerations. Amer Zool 32:370-381

Zieman JC, Macko SA, Mills AL (1984) Role of seagrass and mangroves in estuarine food webs: temporal and spatial changes in stable isotope composition and amino acid content during decomposition. Bull Mar Sci 35: 380-392

Submitted: May 28, 2004; Accepted: November 30, 2004

Proofs received from author(s): May 4, 2005 